\title{
Alternative Disposal Options for High-Level Radioactive Waste
}

\author{
Matthias Englert, Simone Mohr, Saleem Chaudry, and Stephan Kurth \\ Institute for Applied Ecology, Rheinstr. 95, 64295 Darmstadt, Germany \\ Correspondence: Matthias Englert (m.englert@oeko.de)
}

Published: 10 November 2021

\begin{abstract}
Are alternatives to the disposal of high-level radioactive waste in a geology repository conceivable? We present the results of the first phase of a research project on the state of the art in science and technology for alternative disposal options. The project is financed by the Federal Office for the Safety of Nuclear Waste Management.

Most recently, in 2015, the German Commission on the Storage of High-Level Radioactive Waste (Endlagerkommission) evaluated possible disposal technologies and classified them as either promising, conceivable, or to be pursued further. Only final disposal in a geological repository was considered promising. Conceivable, but not immediately available or not advantageous, were storage in deep boreholes (DBs), long-term interim storage (LTIS), and partitioning and transmutation (P\&T). All other alternative disposal options by burial, dilution, or removal from the planet were determined not to be worth pursuing. The Disposal Commission did conclude that none of the three conceivable methods (DBs, LTIS, P\&T) would result in earlier disposal of high-level radioactive waste than the preferred final disposal in a mine. However, it recommended continued tracking and regular monitoring of the future development of alternative disposal options, e.g., disposal in deep boreholes. Finally, in 2017, with the amended Site Selection Act, the federal government specified disposal in a repository mine with the option of retrieval during operation or recovery for 500 years after closure. In a learning site selection process, the Federal Office for the Safety of Nuclear Waste Disposal (BASE) reviews the proposals of the project managing company, the Federal Company for Radioactive Waste Disposal (BGE), and prepares a reasoned recommendation to the federal government for a site with the best possible safety. Part of the reasoned recommendation is, among other things, a discussion of alternative disposal options to final disposal in deep geological formations.

In the presentation, we report on the status of international research on alternative disposal options, discuss advantages and disadvantages of the technologies, and evaluate the potential of the technologies for the disposal of high-level radioactive waste in Germany.

The LTIS is designed as dry storage in a building to be constructed above ground or near the surface and is expected to last for a period of several hundred years. With LTIS it would be possible to gain time for the development of a suitable final disposal option; however, this also postpones the disposal issue indefinitely into the future with undetermined methods. DB storage would involve sinking the storage containers into boreholes with depths of up to $5000 \mathrm{~m}$. This could reduce the expense and be particularly advantageous for smaller inventories, although the potential for the use of engineered barriers would be limited and retrievability precluded according to the current state of the art in science and technology. P\&T is primarily intended to separate long-lived transuranic elements from high-level radioactive waste and then convert them to short-lived fission products by neutron irradiation in reactors. The main goal is to reduce the necessary containment times in the repository by changing the inventory, but the effort to treat the waste would be significant and a repository for high-level nuclear waste is still needed. More exotic ideas for alternative disposal include deep geological injection of liquid waste, waste forms that melt themselves into rock, storage inside the ocean floor or subduction zones, shipment to space, burial in ice sheets, or dilution in the atmosphere and oceans. None of these exotic options is currently being actively pursued.
\end{abstract}


Kurzfassung. Sind Alternativen zur Entsorgung hochradioaktiver Abfälle in einem Endlager denkbar? Wir präsentieren die Ergebnisse der ersten Phase eines Forschungsvorhabens, das den aktuellen Stand von Wissenschaft und Technik zu alternativen Entsorgungsoptionen erfasst. Das Vorhaben wurde durch das Bundesamt für die Sicherheit der nuklearen Entsorgung beauftragt.

Zuletzt hat die Endlagerkommission 2015 mögliche Entsorgungstechnologien bewertet und sie in aussichtsreiche, in denkbare und in nicht weiter zu verfolgende Technologien eingeteilt. Als aussichtsreich wurde dabei nur die Endlagerung in einem Bergwerk eingeschätzt. Denkbar, aber nicht unmittelbar verfügbar oder nicht vorteilhaft seien die Lagerung in tiefen Bohrlöchern (TB), die Langzeitzwischenlagerung (LZZL) und die Partitionierung und Transmutation (P\&T). Alle anderen alternativen Entsorgungsoptionen durch Vergraben, Verdünnen oder Vom-Planet-Entfernen wurden als nicht weiter zu verfolgend eingestuft. Die Endlagerkommission kam zwar zu der Einschätzung, dass keine der 3 denkbaren Methoden (TB, LZZL, P\&T) zu einer früheren Entsorgung der hochradioaktiven Abfälle führen würde als die bevorzugte Endlagerung in einem Bergwerk. Sie empfahl aber eine weitere Verfolgung und regelmäßige Beobachtung der zukünftigen Entwicklung alternativer Entsorgungsoptionen, z.B. der Entsorgung in tiefen Bohrlöchern. Mit dem novellierten Standortauswahlgesetz legte die Bundesregierung 2017 die Entsorgung in einem Endlagerbergwerk mit der Möglichkeit der Rückholung während der Betriebsphase bzw. der Bergung für 500 Jahre nach Verschluss fest. Das Bundesamt für die Sicherheit der nuklearen Entsorgung (BASE) prüft in einem lernenden Standortauswahlverfahren die Vorschläge des Vorhabenträgers, der Bundesgesellschaft für Endlagerung mbH (BGE), und erarbeitet einen begründeten Vorschlag an die Bundesregierung für einen Standort mit der bestmöglichen Sicherheit. Teil der begründeten Empfehlung ist u. a. eine Diskussion alternativer Entsorgungsoptionen zur Endlagerung in tiefen geologischen Formationen.

In der Präsentation berichten wir über den Stand der Forschung zu alternativen Entsorgungsoptionen, diskutieren Vor- und Nachteile der jeweiligen Technologien und bewerten das Potenzial der Technologien für die Entsorgung hochradioaktiver Abfälle in Deutschland.

Die LZZL wird als trockene Lagerung in einem oberirdisch oder oberflächennah zu errichtenden Lagergebäude über einen Zeitraum von mehreren hundert Jahren konzipiert. Mit der LZZL wäre es möglich, Zeit für die Entwicklung einer geeigneten endgültigen Entsorgungsoption zu gewinnen, allerdings wird damit auch die Entsorgungsfrage auf unbestimmte Zeit mit unbestimmten Methoden in die Zukunft verschoben. Bei der Lagerung in TB sollen Lagerbehälter in Bohrlöchern mit Tiefen von bis zu $5000 \mathrm{~m}$ versenkt werden. Dies könnte den Aufwand verringern und v. a. für kleinere Inventare von Vorteil sein, auch wenn die Möglichkeiten für eine technische Barrierefunktion eingeschränkt und Bergbarkeit nach heutigem Stand von Wissenschaft und Technik ausgeschlossen ist. Bei P\&T sollen v. a. langlebige Transurane aus den hochradioaktiven Abfällen abgetrennt und anschließend durch Neutronenbestrahlung in Reaktoren in kurzlebige Spaltprodukte umgewandelt werden. Hauptziel ist es, durch die Veränderung des Inventars die notwendigen Einschlusszeiten im Endlager zu verringern; allerdings wäre der Aufwand zur Behandlung der Abfälle erheblich, und ein Endlager wird weiterhin benötigt. Exotischere Ideen zur alternativen Entsorgung sind die tiefengeologische Injektion von flüssigen Abfällen, sich in das Gestein des tiefen Untergrundes einschmelzende Abfallformen, die Lagerung im Ozeanboden oder in Subduktionszonen, die Verbringung in den Weltraum oder in Eisschilde oder die Verdünnung in der Atmosphäre und den Ozeanen. Keine dieser exotischen Optionen wird international derzeit aktiv verfolgt. 